\title{
Determination of Mass Attenuation Coefficients of High Strength Lightweight Concrete Which Producing Using Raw Perlite Aggregate
}

\author{
İsmet Ulusu ${ }^{1}$, Demet Y1lmaz ${ }^{2}$, Zeynep Uzunoğlu ${ }^{3}$, Yunus Akaltun*4
}

\author{
${ }^{1}$ Erzincan Binali Yıldırım University, Faculty of Engineering, Department of Civil Engineering, \\ Erzincan, Turkey \\ ${ }^{2}$ Atatürk University, Faculty of Sciences, Department of Physics, Erzurum, Turkey \\ ${ }^{3}$ Ağr İbrahim Çecen University, Patnos Vocational School, Department of Electronics and \\ Automation, Ağrı, Turkey \\ ${ }^{4}$ Erzincan Binali Y1ldırım University, Faculty of Engineering, Department of Electrical-Electronic \\ Engineering, Erzincan, Turkey
}

Geliş / Received: 05/09/2018, Kabul / Accepted: 17/12/2018

\begin{abstract}
The development of technology increases the environmental pollution and radiological effects. In the present work, the radiation effects were determined experimentally, in the high strength lightweight concrete according to water /cement ratio. Also, the mass attenuation coefficients of the high strength lightweight concrete samples which producing with perlite aggregate were determined. The measurements were performed using a high-purity germanium detector. Ten different gamma rays energies were used. It is observed that the mass attenuation coefficients of the concrete samples are decreasing with the increasing photon energies. The concrete obtained with perlite aggregate can be used for protect from the radiation.
\end{abstract}

Keywords: Cement, Mass Attenuation Coefficient, Perlite, Concrete.

\section{Ham Perlit Agrega Kullanılarak Üretilen Yüksek Mukavemetli Hafif Betonun Kütle Zayıflamasının Belirlenmesi}

$\ddot{O} z$

Teknolojinin gelişimi ile çevre kirliliği ve radyolojik etkiler artmıştır. Bu çalışmada, ham perlite agregası kullanılarak üretilen yüksek dayanımlı hafif betonda su-çimento oranının radyasyona etkisi deneysel olarak belirlenmiştir. Ayrıca, beton numunelerin perlit agregalı kütle zayıflama katsayıları belirlenmiştir. Ölçümler, yüksek saflıkta bir germanyum detektörü kullanılarak gerçekleștirilmiştir. Farklı gama ışın enerjileri kullanılarak beton örneklerinin kütle soğurma katsayılarının artan foton enerjileri ile azaldığı gözlenmiştir. Perlit agregası ile elde edilen betonun radyasyondan korunmak için kullanılabilir olduğu ortaya çıkmıştır.

Anahtar Kelimeler: Çimento, Kütle Soğurma Katsayısı, Perlit, Yüksek Dayanımlı Hafif Beton.

\section{Introduction}

The light weight concrete, which has been used since antique Roman times, has become popular due to its low unit weight, high durability and good heat insulation. Especially, volcanic origin lightweight aggregates cause increase in strength, durability and heat insulation properties of the concrete due to their pozzolanic activities that reacts with free and reactive agents comes out of the cement hydration. Light weight concrete shows quite different properties depending on the production and used materials. With the advance and wide use of the technology, various equipment and materials used for the benefit of the human being have become dangerous to human health due to emission of the radiation. Especialy; hospitals, industry, research centers, nuclear reactors, and some of devices and materials used in agricultural sector have negative effects even though they provide quite a bit of benefits for human beings. There are three major proposals to minimize effects of the radiation on society, employees, patients, and workers. These proposal are used to keep the residents away 
from these regions which radiation-emitting apparatus to minimize the time people spend in these regions, and to increase the protection precautions. The most efficient method among these proposals is considered to be use of protective materials. The most commonly materials used for protection are concrete and lime plates covered with lead. The reasons for the usage of concrete are ease and inexpensiveness of its production, and formation of protective layer for both for proton and neutron radioactivity by the concrete. To provide optimum protection from the radiation, the absorption properties of the protective materials need to be known. Concretes can have different properties, due to different mixtures and aggregates. So that there is very limited information on transmission of photons and neutrons by light, normal and heavy weight concrete. Kase et al. (2003) have shown that the radiation absorption or transmission of the concrete do not depend on density but neutron transmission varies with the hydrogen content. Also, the photon transmission varieswith the atomic structure. The perlite aggregate have open and closed porous. Also it has approximately ten percent due to too much variation water inside in pourus space due to perlite is formed by the cooling of the magma in water. This structure of perlite aggregate decreases the radiation transmission of the concrete which produced with this aggregate. Stankovic et al. (2010) demonstrated that the materials and theirratios cannot be determined the desired levels of radiation in concrete in the materials used for the production of the concrete. Common opinion is the radiation absorption of concrete which is directly proportional with its aggregate type and density. Akkurt and Akylldırım (2012) obtained results supporting this common opinion. They have shown that the concrete obtained by the usage of pozzolanic aggregate do not provide ideal radiation absorption dueto its porous structure and low unit weight. Perlite aggregate shows pozzolanic activity due to its nature. So that increasing the strength and cement matrix density by reacting with the free lime released with the hydration of the cement. This increases the durability and lifetime of the concrete.

Table 1. Properties of concretes types.

\begin{tabular}{|c|c|c|c|c|c|c|c|}
\hline & Sample 1 & Sample 2 & Sample 3 & Sample 4 & Sample 5 & Sample 6 & Sample 7 \\
\hline Cement $\left(\mathrm{kg} / \mathrm{m}^{3}\right)$ & 600 & 600 & 550 & 550 & 450 & 450 & 400 \\
\hline Water $\left(\mathrm{kg} / \mathrm{m}^{3}\right)$ & 300 & 240 & 275 & 220 & 225 & 180 & 160 \\
\hline $\begin{array}{c}\text { Super fluidizing } \\
\text { agent }\end{array}$ & $1 \%$ & $1 \%$ & $1 \%$ & $1 \%$ & $1 \%$ & $1 \%$ & $1 \%$ \\
\hline Aggregate (kg) & $\begin{array}{l}100 \% \\
\text { Perlite }\end{array}$ & $\begin{array}{l}100 \% \\
\text { Perlite }\end{array}$ & $\begin{array}{l}100 \% \\
\text { Perlite }\end{array}$ & $\begin{array}{l}100 \% \\
\text { Perlite }\end{array}$ & $\begin{array}{l}100 \% \\
\text { Perlite }\end{array}$ & $\begin{array}{l}100 \% \\
\text { Perlite }\end{array}$ & $\begin{array}{l}100 \% \\
\text { Perlite }\end{array}$ \\
\hline
\end{tabular}




\section{Materials and methods}

In the production of high strength light weight concrete (HSLWC), cement and Erzincan Molla köy raw perlite aggregate were used. Unit weight of perlite aggregate varies between 1020 and $1260 \mathrm{~kg} / \mathrm{m}^{3}$ depending on the aggregate's grading. The mixes grading was prepared due to standard specification for light aggregates for structural concrete (ASTM C330-04) and the relationship of Fuller $\left(\mathrm{P}_{i}=(\sqrt{(d i / D \max )})^{1 / \mathrm{n}}\right)$.

The aggregate was mixed by water (prewetted), $5 \%$ of its weight before the mixing. This is the reason that the light weight aggregates cause a problem by absorbing the water of the concrete during mixing, transfer and placement (pouring/casting). To prevent this, the pre-wetting (adding water to) of the aggregates is needed before the mixture. During mixing, aggregates first put into the mixer. It was mixed about 3 minutes. In a Table 2. Chemical composition and physical properties of the cement used in concrete.separate cup water, plasticizer and cement were mixed to obtain a homogenous mix. The fluid mix was slowly poured into the aggregate in the mixer. This process was completed within about 3 minutes. After, the mixer was operated about 5 minutes to complete the concrete mixing. In the present work, it was determined the radiation effects of water to cement ratio. 7 different mixes were prepared with 4 different cements and 2 different waters to cement ratios, as seen from Table 1. These samples were cured in cure tank for 28 days. All concrete samples were tested according to TS 3114 and ASTM C39. The chemical and physical properties of the cement used in concrete are given in Table 2. The chemical composition of perlite aggregate is given in Table 3.

Table 2. Chemical composition and physical properties of the cement used in concrete.

\section{Chemical composition (\%)}

Silicon dioxide $\quad 74.6$

Titanium dioxide

Aluminum oxide

Ferric oxide

Iron oxide

Manganese oxide

Magnesium Oxide 0.018

Calcium oxide

Sodium oxide

Potassium oxide

Phosphorus pentoxide

0.004

Furnace lost 2.370 
Table 3. Chemical composition of perlite aggregate used in concrete.

\begin{tabular}{|c|c|c|}
\hline Chemical composition & \multicolumn{2}{|c|}{ \% Weight } \\
\hline Calcium oxide & \multicolumn{2}{|l|}{64.02} \\
\hline Silicon dioxide & \multicolumn{2}{|l|}{20.31} \\
\hline Aluminum oxide & \multicolumn{2}{|l|}{5.64} \\
\hline Ferric oxide & \multicolumn{2}{|l|}{3.27} \\
\hline Magnesium oxide & \multicolumn{2}{|l|}{2.09} \\
\hline Sulfur trioxide & \multicolumn{2}{|l|}{2.86} \\
\hline Potassium oxide & \multicolumn{2}{|l|}{0.93} \\
\hline Sodium oxide & \multicolumn{2}{|l|}{0.87} \\
\hline \multicolumn{3}{|l|}{ Physical properties } \\
\hline Density $\left(\mathrm{g} / \mathrm{cm}^{3}\right)$ & \multicolumn{2}{|l|}{3.11} \\
\hline Specific surface $\left(\mathrm{cm}^{2} / \mathrm{g}\right)$ & \multicolumn{2}{|l|}{3489} \\
\hline $\begin{array}{l}200 \text { micrometer sieve coarser } \\
(\%)\end{array}$ & \multicolumn{2}{|l|}{-} \\
\hline $\begin{array}{l}90 \text { micrometer sieve coarser } \\
(\%)\end{array}$ & \multicolumn{2}{|l|}{0.3} \\
\hline 40 micrometer coarser $(\%)$ & \multicolumn{2}{|l|}{8.4} \\
\hline Volumetric expansion & \multicolumn{2}{|l|}{2} \\
\hline Loss on ignition & \multicolumn{2}{|l|}{0.90} \\
\hline Insoluble residue & \multicolumn{2}{|l|}{0.31} \\
\hline \multirow[t]{2}{*}{ Compressive Strength } & 7 day & $\begin{array}{l}38.8 \\
\mathrm{MPa}\end{array}$ \\
\hline & 28day & $\begin{array}{l}45.78 \\
\text { MPal }\end{array}$ \\
\hline
\end{tabular}

The experimental measurements were performed in Prof. Dr. Wolf Weyrich High Energy Spectroscopy Laboratories of Atatürk University, Erzurum, Turkey. The schematic view of the experimental setup is shown in Figure 1.

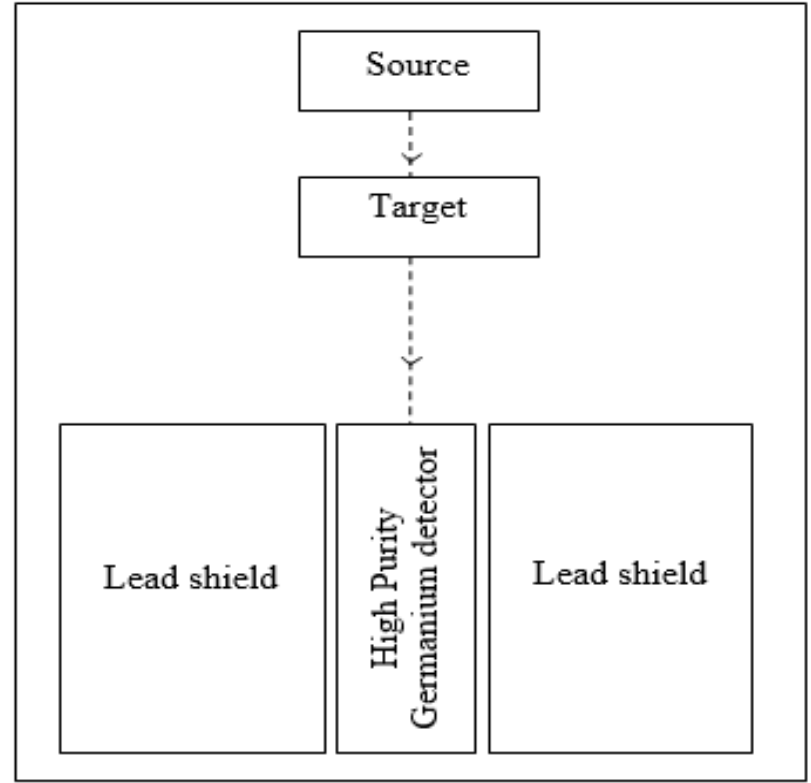

Figure 1. The detection geometry for the determination of mass attenuation coefficients of concrete types (Lead shields have thickness of $5 \mathrm{~cm}$ ).

The mass attenuation coefficients of produced concretes were measured by using a high-purity germanium detector. The highpurity germanium detector has a beryllium window thick of $0.12 \mathrm{~mm}$ and active area of $200 \mathrm{~mm}^{2}$ and a resolution of $182 \mathrm{eV}$ at 5.9 $\mathrm{keV}$. The spectra were recorded by using a Canberra (AccuSpec) PC-based multichannel analyzer card. Operating parameters of the system were governed and controlled by the computer program Genie-2000. The data were collected into 4096 channel of the multichannel analyzer. Data were analyzed by the Origin 7.5 software program. The concrete samples were irradiated at 59.54, $80.99, \quad 121.78, \quad 344.27,356.02,662.62$, 778.20, 964.08, 1112.07 and $1408.01 \mathrm{keV}$ energies emitted from $10 \mu \mathrm{Ci}{ }^{241} \mathrm{Am},{ }^{133} \mathrm{Ba}$, ${ }^{137} \mathrm{Cs}$ and ${ }^{152} \mathrm{Eu}$ point sources. The concrete samples were placed at a distance of $30 \mathrm{~mm}$ from the radioactive source. The measuring time for each target was $1800 \mathrm{~s}$. The spectra were taken with and without the target in the primary incident beam. 
Tablo 4. The experimental mass attenuation coefficients of the concrete types.

\begin{tabular}{|l|l|l|l|l|l|l|l|c|}
\hline \hline \multicolumn{7}{|c|}{$\begin{array}{c}\text { Mass attenuation coefficient }\left(\mathbf{c m}^{2} / \mathbf{g}\right) \\
\text { Snergy (kilo } \\
\text { Sample 3 }\end{array}$} \\
\multicolumn{10}{|c|}{ Sample 4 } & \multicolumn{1}{c|}{ Sample 5 } & Sample 6 & Sample 7 \\
\hline 59.54 & $0.5928 \pm 0.034$ & $0.5869 \pm 0.019$ & $0.5733 \pm 0.032$ & $0.5596 \pm 0.023$ & $0.5423 \pm 0.026$ & $0.5322 \pm 0.021$ & $0.5102 \pm 0.03$ \\
80.99 & $0.4153 \pm 0.024$ & $0.4114 \pm 0.013$ & $0.4056 \pm 0.022$ & $0.3997 \pm 0.017$ & $0.3822 \pm 0.018$ & $0.3724 \pm 0.015$ & $0.3651 \pm 0.02$ \\
121.78 & $0.3420 \pm 0.019$ & $0.3121 \pm 0.009$ & $0.3081 \pm 0.017$ & $0.3061 \pm 0.013$ & $0.2954 \pm 0.014$ & $0.2854 \pm 0.011$ & $0.2714 \pm 0.01$ \\
344.27 & $0.2308 \pm 0.030$ & $0.2212 \pm 0.007$ & $0.2125 \pm 0.012$ & $0.2015 \pm 0.008$ & $0.1908 \pm 0.009$ & $0.1865 \pm 0.007$ & $0.1752 \pm 0.01$ \\
356.02 & $0.1999 \pm 0.011$ & $0.1845 \pm 0.006$ & $0.1715 \pm 0.009$ & $0.1666 \pm 0.007$ & $0.1542 \pm 0.009$ & $0.1425 \pm 0.006$ & $0.1325 \pm 0.02$ \\
661.62 & $0.1523 \pm 0.009$ & $0.1425 \pm 0.005$ & $0.1356 \pm 0.007$ & $0.1254 \pm 0.005$ & $0.1125 \pm 0.005$ & $0.1111 \pm 0.004$ & $0.1025 \pm 0.01$ \\
778.20 & $0.1423 \pm 0.008$ & $0.1411 \pm 0.005$ & $0.1309 \pm 0.007$ & $0.1169 \pm 0.005$ & $0.1111 \pm 0.005$ & $0.1023 \pm 0.004$ & $0.1001 \pm 0.02$ \\
964.08 & $0.1279 \pm 0.007$ & $0.1261 \pm 0.004$ & $0.1254 \pm 0.007$ & $0.1137 \pm 0.005$ & $0.1107 \pm 0.005$ & $0.1008 \pm 0.004$ & $0.0945 \pm 0.03$ \\
1112.07 & $0.1199 \pm 0.006$ & $0.1182 \pm 0.004$ & $0.1173 \pm 0.006$ & $0.1111 \pm 0.005$ & $0.1100 \pm 0.005$ & $0.1002 \pm 0.004$ & $0.0922 \pm 0.05$ \\
1408.01 & $0.1155 \pm 0.006$ & $0.1053 \pm 0.003$ & $0.1021 \pm 0.006$ & $0.1010 \pm 0.004$ & $0.1005 \pm 0.005$ & $0.0965 \pm 0.004$ & $0.0912 \pm 0.02$ \\
\hline \hline
\end{tabular}

Table 5. The theoretical mass attenuation.

\begin{tabular}{|l|l|l|}
\hline $\begin{array}{l}\text { Energy } \\
\text { kilo } \\
\text { electronvolt) }\end{array}$ & $\begin{array}{l}\text { Mass attenuation coefficient } \\
\left(\mathrm{cm}^{2} / \mathrm{g}\right) \\
\text { Cement }\end{array}$ \\
\hline 59.54 & 0.501 & 0.269 \\
\hline 80.99 & 0.290 & 0.197 \\
\hline 121.78 & 0.181 & 0.154 \\
\hline 344.27 & 0.103 & 0.101 \\
\hline 356.02 & 0.101 & 0.100 \\
\hline 661.62 & 0.0769 & 0.0741 \\
\hline 778.20 & 0.0712 & 0.0704 \\
\hline 964.08 & 0.0643 & 0.0641 \\
\hline 1112.07 & 0.0599 & 0.0587 \\
\hline 1408.01 & 0.0531 & 0.0523 \\
\hline
\end{tabular}

The background count rate was subtracted from the measurements. The mass attenuation coefficients $\left(\mathrm{cm}^{2} / \mathrm{g}\right)$ is obtained by;

$$
\frac{\mu}{\rho}=\frac{1}{\rho x} \ln \left(\frac{I_{0}}{I}\right)
$$

where $\mathrm{x}$ is the material thickness, $\rho$ is the material density, I and I0 are the background subtracted number of counts recorded in detector with and without concrete material between detector and source, respectively. The theoretical mass attenuation coefficients were obtained by using a computer program.

\section{Results and Discussion}

There is no consensus on what the mix of the concrete should be to protect from radiation. Şahin et al. (2011) showed that the mass attenuation coefficient increases with the increasing cement amount and the decreasing coefficients of cement and perlite water cement ratio in conventional concrete. Ogundare et al. (2012) showed that the mass attenuation coefficient does not depend only unit weight. The mass attenuation coefficient depends on the structure of the aggregate used in the concrete. Aminian et al. (2007) have investigated two concrete samples of different aggregate with unit weight 3.11 $\mathrm{gr} / \mathrm{cm}^{3}$ and $2.6 \mathrm{gr} / \mathrm{cm}^{3}$. They have shown that both of samples can be used to protect from radiation. But the density (unit weight) is not an essential criterion. Akkurt and Aky1ldırım have Perlite aggregate can be used to produce 
concrete for protect from the radiation. So it can be said that the mass attenuation coefficient varies significantly based on the structure of the aggregate used in the production of the concrete. The overall error in the experimental parameters is the sum of the uncertainties in different factors, namely, the evaluation of peak areas (2.3-4.7\%), target mass thickness (1.5-4.2\%) and statistical error $(<1.00 \%)$. Total errors affecting the experimental parameters are calculated between $2.9-6.4 \%$. compared the mass attenuation coefficient of the conventional concrete and concrete with the pozzolanic aggregate. They obtained that the mass attenuation coefficient of the pozzolanic concrete is lower than the conventional concrete due to porous structure and low unit weight of pozzolanic aggregate. De Oliveira et al. showed that the mass attenuation coefficient of the concrete varies depending on the porosity and structure of the concrete. The theoretical mass attenuation coefficients of cement and perlite are given Table 5. Also, the experimental mass attenuation coefficients of the concrete

\section{References}

Aitcin, P.C. 1998. High Performance Concrete, E \& FN Spon, London and New York, USA.

Akkurt, I., Basyiğit, C., Kılıncarslan, S., Mavi, B., Akkurt, A. 2006. Radiation Shielding of concrete containing different aggregates. Cement and Concrete Composites, 28, 153-157.

Akkurt, I., Akyıldırım, H. 2012. Radiation transmission of concrete including pumice for 662, 1173 and $1332 \mathrm{keV}$ gamma rays. Nuclear Engineering and Design, 252, 163-166.

Aminian, A., Nematollahi, M.R., Haddad, K., Mehdizadeh, S. 2007. Determination of shielding parameters for different types of concretes by Monte Carlo methods, samples are given Table 4. As seen from Table 4, the mass attenuation coefficients are decreasing with the increasing photon energies. Also, the mass attenuation coefficients decrease with the decreasing the cement amount. Şahin et al (2011) have shown that the mass attenuation coefficient of the conventional concrete increases with the increasing cement amount. Since the mass attenuation coefficient of the cement is higher than the aggregate used in the production of the concrete, the mass attenuation coefficient increases with the increasing cement amount.

\section{Conclusions}

In this work, the mass attenuation coefficients of the high strength lightweight concrete samples were determined. It can be concluded that perlite is an important aggregate. The addition of perlite as an aggregate in concrete is an alternative option to be used for the purpose of radiation shielding. Also, the mass attenuation coefficient varies with aggregate structure in the same unit weight

13. International Conference on Emerging Nuclear Energy Systems (ICENES), Istanbul, Turkey, June 3-8.

Berger, M.J., Hubbell, J.H. 1987/1999. XCOM: Photon cross-sections database, Web version 1.2, National Institute of Standards and Technology, Gaithersburg, MD20899, USA. http://physics.nist.gov/ xcom (Originally published as NBSIR 873597 XCOM: Photon Cross Sections on a Personal Computer).

Chandara, S., Berntsson, L. 2003. Lightweight Aggregate Concrete, Noyes Publications, New York, USA.

Demir, D., Keleş G. 2006. Radiation transmission of concrete including 
boron waste for 59.54 and $80.99 \mathrm{keV}$ gamma rays. Nuclear Instruments In Physics Research Section B-Beam Interactions With Materials And Atoms, 245, 501-504.

Hossain, K.M.A. 2004. Properties of Volcanic Pumice Based Cement and Lightweight Concrete, Cement and Concrete Research, 34, 283-291.

Kase, K.R., Nelson, W.R., Fasso, A. Liu, J.C., Mao, X., Jenkins, T.M., Kleck, J.H. 2003. Measurements of accelerator produced leakage neutron and photon transmission through concrete. Health Physics, 84, 180-187.

Mann, W.B., Rytz, A., Spernol, A. 1998. Radioactivity Measurements: Principal and Practice, Oxford, UK, Pergoman Press.

Neville, A.M. 1996. Properties of Concrete; John Wiley and Sons, Fourth edition, New York, USA.

Ogundare, F.O., Ogundele, S.O., Akerele, O.O. Balogun, F.A. 2012. Low energy broad beam photon shielding data for constituents of concrete. Journal of Applied Clinical Medical Physics, 13, 3525-3533.

Oliveira, Jr. J.M. De., Martins, A.C.G., De Milito, J.A. 2004. Analysis of concrete material through gamma ray computerized tomography. Brazilian Journal of Physics, 34, 1020-1023.

Stanković, S.J., Ilić, R.D., Janković, K., Bolović, D., Lončar, B. 2010. Gamma radiation absorption characteristics of concrete with components of different type materials. Acta Physica Polonica A, 2010, 117, 812-816.

Şahin, R., Polat, R., İçelli, O., Çelik, C. 2011. Determination of transmission factors of concretes with different water/cement ratio, curing condition and dosage of cement and air entraining agent. Annals of Nuclear Energy, 38, 1505-1511. 